Advances in Social Science, Education and Humanities Research, volume 118

9th International Conference for Science Educators and Teachers (ICSET)

\title{
CAREER OPTION AND ITS PROBLEM
}

\author{
Wenny Hulukati \\ Faculty of Education, State University of Gorontalo \\ Email: wennyhulukati@ung.ac.id
}

\begin{abstract}
Problem statement of this research is students have not yet understood career option. This research aims to analyze students' career option in class X of SMA Prasetya Kota. This is a quantitative descriptive research with one variable namely students' career option. Research samples are 59 students. Data collection instrument uses questionnaire students' career option. Findings of data analysis reveal that (1) indicator of career planning is in percentage of 67\% (Sufficient), (2) indicator of career exploration is in percentage of $69 \%$ (Sufficient), (3) indicator of knowledge about making career decision is in percentage of $69 \%$ (Sufficient). This research finding can be used as information of guidance and counseling teacher that students of SMA Prasetya Gorontalo City need service of guidance and counseling particularly about career option.
\end{abstract}

Keywords: Career Option, problem, student.

\section{INTRODUCTION}

Introduction and understanding about either advanced education or career is a process of vocational development stage of students to select appropriate career option. It requires to be performed as early as possible due to avoiding mistake in making decision for the career. Decision to select certain job, position and career is a sequence for decisions having been made by individuals in their past stages of life.

According to [1], career problems of SMA (Senior High School) students are they lack of understanding in selecting appropriate study program based on their ability and interest, they do not have sufficient information about job vacancy, they are still confused to select job, they are still unable to select job based on the ability and interest due to anxiety of obtaining job after graduated, they have not selected yet the college they want to enter or particular advanced education after graduated from Senior High School, they do not have description about characteristics, requirements, ability and skill needed in certain job as well as prospect of the job for the future career.
In the development stages, students of Senior High School are in adolescence age between 15-18 years in which they have had obvious career option compared to children. The adolescents in this stage consider personal values to be important in process of career option. Commonly, an adolescent starts to see the important thing for himself/herself and know about various lifestyles prepared by the job.

Career option requires long time and is influenced by several factors, either supporting or obstacle factor. Generally, career option is a process of individual as effort of preparing self for entering job stages [2]. Theory of Holland [in 3] expresses that "Career selection or position is a result of interaction between factor of heredity with all influences of culture, friends of parents, and those adult people who are considered having important role". According to [4], career selection is a process when adolescents lead themselves to a new stage of life, seeing their position in making the career decision". In addition, [5] argues that career selection is a way or effort of someone or selecting one between many positions or jobs which give expectation 
for improvement and based on what is expected".

Ginzberg, Ginzburg, Axelrad, \&Herma [in 6] express that development in process of job option encompasses three main stages namely fantasy, tentative and realistic. Both of tentative and realistic are divided into several stages. Tentative age covers age of 11 to 18 years (period of students in SMP and SMA) and it encompasses four stages namely interest, capacity, value and transition. Meanwhile, realistic age is when those adolescents study in the university or started to work. This age encompasses exploration, crystallization and specification.

[7] mentioned in Donal Super's opinion that "Process of career development is divided into five stages namely growth phase from born to approximately 15 years, where children develop various potentials, characteristic view, attitude, interest, needs which integrated in self-concept structure, exploration phase from 15 to 24 years, where adolescents think of various alternatives of position, however binding decision is not made yet, establishment phase from 25 to 44 years which is described by thorough effort to establish themselves through details of experience during undergoing certain career, maintenance phase from 45 to 64 years, where adult people adjust themselves in comprehending position, decline phase if people enter retire age and require to seek new lifestyle after leaving the position:.

There are several factors which influence an individual in planning career [7] namely:

1. Life values, namely ideal pursued by people anywhere and anytime. These values become way of life.

2. Physical condition, namely physical characteristics owned by people. For certain jobs, physical condition is applied.

3. Society, namely environment of social-cultural where young adolescent are grown. This environment is wide and influences view of many things clung by family which should be instilled based on turn.

4. Socio-economic condition of a country or region, namely slow and rapid economic growth, stratification of society in socio-economic group, and diversification of society for either opened or closed groups.

5. Position of children in the family. Children who have elder siblings, definitely, ask opinion and view in regard of career planning thus they have additional wider view than those who do not have siblings.

6. Family view about role and obligation of son and daughter which have caused both psychological and social-cultural impact.

7. Other people who stay at the same house except parents, biological brothers and sisters and expectation of family about the future of children will give great influence for them in arranging and planning the career.

8. Socio-economic level of family namely education level of parents, income of parents, position of father or father and mother, living area and tribe. These status will also determine the probable school education level, number of acquaintance is a key for several positions which are considered still based on certain social status.

9. Peer friends interaction namely varied views and expectations about the future revealed in daily interaction. Optimistic view and expectation will 
have good impression compared to complaints.

10. School education, namely view and attitude communicated to students performed by guidance staffs and teachers about values of working, high and low of social status of positions and appropriateness of certain position.

11. Lifestyle and family condition as well as parents' marital status namely in which family condition children are grown. It is related to whether or not supporting in which it will influence children in planning and making decision about either advanced education or jobs.

[8] expressed several indicators in career option which are: (1) career planning. Aspect of career planning according to Super (in Sharf, 1992) is "activity of seeking information and to what extent involvement of individual in the process". This condition is supported by knowledge about kinds of element in any job. This indicator is being aware of insight and career preparation, understanding consideration of career option alternative and having future career planning. (2) Career exploration. This aspect is "individual ability to seek information of career from various career sources such as parents, siblings, relatives, friend, teacher of the field of study, school counselor and etc". This aspect is correlated with number of career information obtained by students from those sources. Indicator of this aspect is collecting career information from various sources and utilizing it. (3) Knowledge about career decision making. This aspect is 'students' ability in using both knowledge and thought in planning the career". This concept is based on students' demand to make career decision, by having assumption if they know how others make career decision thus they are expected to do the same.

\section{METHOD}

This is a quantitative descriptive research with one design of variable namely career option. Research populations are 59 students in class X of SMA Prasetya City of Gorontalo. Meanwhile, its samples are determined based on entire population. Technique of data collection uses likert scale distributed to respondents of research. Then, research data are analyzed descriptively by using statistical of percentage calculation (\%) with formula of $(\mathrm{P}=\mathrm{F} / \mathrm{N} \times 100 \%)$.

\section{RESULT AND DISCUSSION}

Data obtained from processing of questionnaire about career option of students in class X of SMA Prasetya City of Gorontalo are then processed by using percentage calculation. The findings of them are shown below in form of graphic.

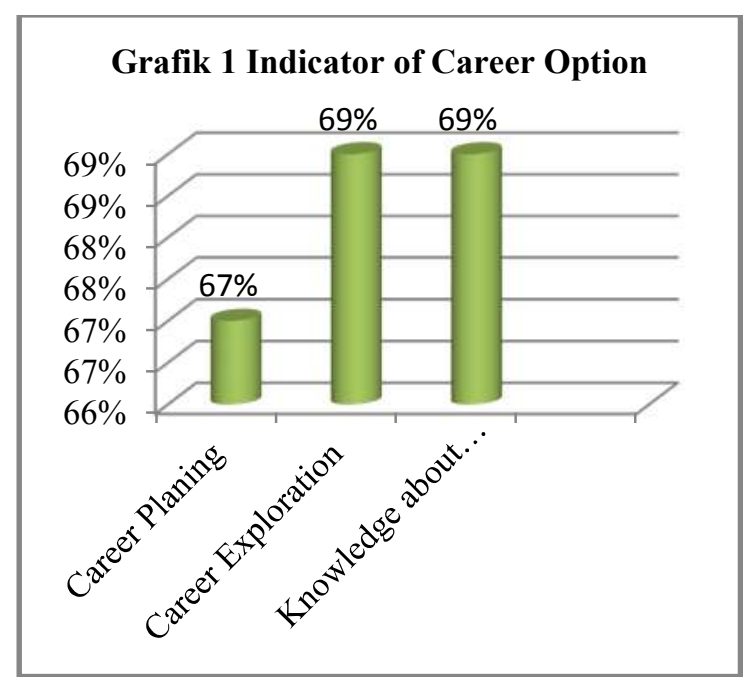

Graphic 5.1 shows that indicator of career planning is in percentage of $67 \%$ (sufficient), indicator of career exploration is in percentage of $69 \%$ (sufficient), and 
indicator of knowledge about making career decision is in percentage of $69 \%$ (sufficient).

Based on the analysis, it obtains students' career option that

1. Indicator of career planning is in percentage of $67 \%$ (sufficient)

Career planning is one of the most important aspects in individual career development [9]. Then, Dillard [in 10] states that career planning is process of achieving individual career marked by presence of obvious goal after finishing education, obvious ambition for the job, encouragement to improve in field of education and dreamt job, realistic perception towards self and environment, ability of grouping demanded job, give positive reward towards job and values, independence in process of making decision, maturity in making decision and show realistic ways in achieving ambition of job. [11] stated that all students will make realistic life career plan encompasses their education and future career path. This plan is not intended to force them making earlier career decision, yet it is to ensure that they have needed knowledge and understanding to avoid academic decision or career they may regret later.

2. Indicator of career exploration is in percentage of $69 \%$ (sufficient)

Career exploration is a complex psychology process namely effort to seek and study information about selfcharacteristic related to weakness and strength and study information about career environment related to opportunities and threat in term of achieving career goal [12]. Understanding career exploration is very crucial for young adolescents in order to be able to select and obtain appropriate information and able to apply students' interest and talent based on what is gifted. Career exploration is indispensable for students in order to be able to make decision and plan the career. As a matter of fact, mostly students' interest for certain job does not balanced with good knowledge and skill either academically or based on their interest and talent to support the job [12].

3. Indicator of knowledge about making career decision is in percentage of $69 \%$ (sufficient)

Every student requires to be able to make decision in having position which will be undertaken for future, based on self understanding and life situation as well as guided in relevant information processing about students' environment. The ability should be instilled since early in order to make students more understanding themselves, environmental and process of making decision as well as to be better in preparing themselves in cases of knowledge, skill attitude and value needed by students' [13]. One of problems is often faced by students particularly those who are in SMA level is their inability or difficulty in making career decision. Most of them are unable to select and decide their future career. This is caused by lack of knowledge about department or study program they are going to be chosen after graduated from Senior High School, as well as appropriate job and based on their talent and ability. As it is known that sometimes, students select a department or study program without mature consideration or just following friends, without seeing and considering characteristics, talent and ability [14].

\section{CONCLUSION}

Based on research findings, it can be concluded that indicator of career planning is in percentage of $67 \%$ 
(sufficient), indicator of career exploration is in percentage of $69 \%$ (sufficient), and indicator of knowledge about making career decision is in percentage of $69 \%$ (sufficient). Problem encountered by students is lack of understanding or knowledge about career option. This finding can be information for teacher of guidance and counselling that students of SMA Prasetya City of Gorontalo need service of guidance and counselling about career option.

\section{REFERENCES}

[1] Supriatna, Mamat. 2009. Career Guidance Service in Secondary School. Ministry of National Education Universitas Pendidikan Indonesia. Bandung.

[2] Setyawardani, Fidiana L. 2009. Differences in Emotional Intelligence, Learning Behavior and Stress Levels of Junior and Senior Accounting Students, Journal of Ekuites. Vol. 13, No. 4.

[3] Akbar, Hanifan. 2011. Trend of Career Selection Based on Learning Style in Students of Class XII. (On line). (http://repository.usu.ac.id, Retrieved 20 March 2017).

[4] Oktaviani, Widya. 2006. Perception of Accounting Students at Bengkulu University Regarding Auditor's Work Environment on Career Options as Auditor. (On line). (http://digilib.unismu.ac.id Accessed March 13, 2017).

[5] Yunitasari, Riski. 2006. Factors Affecting Career Selection. (Online), (http://digilib.unimus.ac.id, Retrieved 17 March 2017).

[6] Munandir. 1998. Career Guidance Program at School. Ministry of Education and Culture Directorate General of Higher Education. Jakarta.

[7] Winkel, W. S. \& Sri, Hastuti. 2006. Guidance and Counseling in Educational Institutions. Media Abadi. Yogyakarta.
[8] Sharf, Richard S. 1992. Applying Career Development Theory to Counseling. Brooks/Cole Publisihing Company. USA.

[9] Atmaja, Twi Tandar. 2014. Efforts to Improve Student Career Planning Through Career Guidance with Media Module Usage. Journal PSIKOPEDAGOGIA. Vol. 3, No. 2. Pg. 58-67

[10] Adiputra, Sofwan. 2015. Use of Modeling Techniques on Student Career Planning. Journal of Counseling Focus. Volume 1 No. 1, Pg. 45-56.

[11] Vinci Ng dan Mantak Yuen. 2016. Career Guidance and Counseling in an International School in Hong Kong: Literature Review and a School Counselor's Reflection. Asian Journal of Counselling, Published online first, 31 March 2016. pp. 1-17

[12] Purwanta, Edi. 2012. Factors Affecting Career Exploration of Junior High School Students. Jurnal Cakrawala Pendidikan. Th XXXI. No. 2. Pg. 228243.

[13] Priyatno, Tovik. 2016. Efforts to Increase Understanding Career Exploration Through Group Guidance Services with Group Discussion Techniques. Journal PSIKOPEDAGOGIA. Vol. 5, No. 1. Pg. 49-56.

[14] Fasha, Fadilla., Sinring, A., and Aryani, Farida. 2015. Development of E-Career Model To Improve Student Career Decision of SMA Negeri 3 Makassar. Journal of Educational Psychology \& Counseling. Volume 1 Number 2. Page. 170-179. 